\title{
THE ROLE OF SOME ORGANIC MATTERS ON THE KEEPING QUALITY AND EXTENDING THE VASE LIFE OF CARNATION (DIANTHUS CARYOPHYLLUS CV. AMERICA) CUT FLOWERS
}

Amal A. Zaky; Soad A.M. Khenizy and Ehsan E.A. Eldeeb

Ornamental Plants and Landscape Gardening Res. Dept., Hort. Res. Inst., ARC, Giza, Egypt.

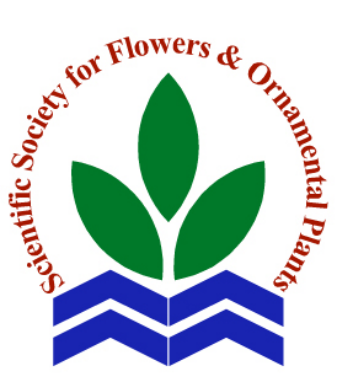

Scientific J. Flowers \& Ornamental Plants, 1(2):163-170 (2014).

Received:

$21 / 8 / 2014$

Revised by:

Prof. Dr. E.M. Badawy, Cairo Univ.

Prof. Dr. F.S. Badran, Minia Univ.
ABSTRACT: Dianthus caryophyllus is one of the most important produced cut flowers. The present experiment focuses on the effects of some organic matters on postharvest longevity and other related characters of Dianthus caryophyllus cv. America cut flowers. The obtained results emphasized that all preservative solutions caused a marked increment in the studied characters as compared to distilled water (control). In this regard, the flowers hold in the preservative solution of $2 \%$ sucrose + either garlic extract $(1 \mathrm{ml} / 1)$ or jasmine oil $(0.030 \%)$ significantly prolonged vase life, increased flowers fresh weight $(\%)$ and water uptake $\left(\mathrm{cm}^{3}\right)$, reduced the depletion of sugars content and increased anthocyanin content in the flowers. Moreover, the treatment of garlic extract $(1 \mathrm{ml} / \mathrm{l})+2 \%$ sucrose increased markedly the flower diameter $(\mathrm{cm})$, flower opening percentage and the other related characters. Fenugreek extract $(1 \mathrm{~g} / \mathrm{l})+2 \%$ sucrose affected positively on the studied characters of carnation cut flowers. Preservative solution containing $2 \%$ sucrose + either garlic extract ( 1 $\mathrm{ml} / \mathrm{l})$ or jasmine oil $(0.030 \%)$ clearly reduced the number of bacteria and fungi in the vase solutions as compared to control or other treatments used.

Key words: Organic matters, carnation, cut flowers, vase life, microorganisms.

\section{INTRODUCTION}

Dianthus caryophyllus cv. America belongs to family Caryophyllaceae and commonly known as carnation. It is native to the Mediterranean region, these flowers are attractive and have much ornamental utilization, cut off with long stalk and picking at mature bud stage for facilitating handling, transportation and reduces damage possibilities. Picked can be done also in an earlier stage. The sensitivity of these flowers to ethylene shortens vase life as it stimulates a quick opening of flowers which may constitute a big loss to producers and traders.

Since jasmonates (Jasmine oil) were discovered in Jasmine flowers (Jasminum grandifloum L.) (Ueda, 1991); two effective components were determined, i.e. methyl jasmonate (MJ) and jasmonic acid (JA). Methyl jasmonate (MJ) is a natural growth regulator which induces plant defense responses. It was tested for postharvest to control the grey mould disease in various cut rose cultivars (Meir et al., 1998).

Garlic (Allium sativum) contains $0.10-$ $0.36 \%$ of a volatile oil composed of sulfurcontaining compounds, i.e. allicin, diallyl disulfide, diallyl trisulfide and others (Duke, 1992). Naganawa et al. (1996) stated that, ajoene, a garlic-derived sulfur-containing compound that prevents platelet aggregation, exhibited broad-spectrum antimicrobial activity.

Fenugreek (Trigonella foenum-graecum L.) contains the active constituents such as alkaloids, flavonoids, steroids, saponins etc. 
The seeds are affecting as aromatic, bitter, carminative, galactogouge and antibacterial agents, containing a dietary fiber $(50 \%)$ and protein $(30 \%)$. The chemical components of fenugreek seeds include a large carbohydrate fraction (mucilaginous fiber, galactomannan); $20-30 \%$ proteins high in tryptophan and lysine; pyridine-type alkaloids; flavonoids; free amino acids (4hydroxyisoleucine, arginine, lysine, histidine); saponins; glycosides; vitamins, minerals, (28\%) mucilage, (22\%) proteids, $5 \%$ of a stronger-smelling, bitter fixed oil and volatile oils. The seeds of the fenugreek herb possess toxic oils, and other constituents of the fenugreek leaf have been shown to be toxic to bacteria, parasites and fungi (Snehlata and Payal, 2012).

This study aims to investigate the effect of using the environmental safer materials in the keeping quality of carnation cut flowers.

\section{MATERIALS AND METHODS}

This research was carried out at the Hort. Res. Inst., ARC, Giza, Egypt, on January $1^{\text {st }}$ for two successive seasons 2011 and 2012, using uniformly carnation flowers (Dianthus caryophyllus) cv. America, obtained at star stage (when petals emerge about $0.5 \mathrm{~cm}$ above the calyx) in the early morning from a commercial farm. They were placed in ice cold water for three hours and the flower stems were adjusted to $50 \mathrm{~cm}$ long.

The layout of the experiment was completely randomized design with three replicates per treatment; each replicate consisted of 4 flowers, i.e. 12 flowers in each treatment.

The flowers were placed in a vase $(500$ $\mathrm{ml}$ ) containing $400 \mathrm{ml}$ preservative solution containing:

\section{1- Distilled water (control).}

2- 8-Hydroxyquinoline citrate (8-HQC) at $200 \mathrm{mg} / \mathrm{l}+2 \%$ Sucrose.

3- Jasmine oil dissolved in ethanol at the concentration of $0.030 \%+2 \%$ Sucrose.
4- Fenugreek extract (filtered through Watman filter paper) at $1 \mathrm{~g} / 1+2 \%$ Sucrose.

5- Fenugreek extract (filtered through Watman filter paper) at $2 \mathrm{~g} / 1+2 \%$ Sucrose.

6- Garlic extract at $1 \mathrm{ml} / 1+2 \%$ Sucrose.

7- Garlic extract at $2 \mathrm{ml} / 1+2 \%$ Sucrose.

The experiment was carried out under lab conditions (24 hrs fluorescent light at $1000 \mathrm{Lux}, 18 \pm 2^{\circ} \mathrm{C}$ and $\left.40-50 \% \mathrm{RH}\right)$.

\section{The following data had been recorded:}

1- Flower vase life: the shelf life period (day) was defined as the number of days between full opening of flowers to clear enrolling and wilting of the petals.

2- Flower opening percentage was determined from star stage to complete opening stage.

3- Flower diameter $(\mathrm{cm})$ was measured by vernier caliper after complete opening.

4- Flower fresh weight increase percentage.

5- Water uptake $\left(\mathrm{cm}^{3}\right)$ at the end of shelf life.

6- Bacteria counts: The samples of the vase solutions were taken at the end of shelf life period of control according to the method described by (Postage, 1969).

7- Fungi counts: The samples of the vase solutions were recorded at the end of shelf life period of control according to the method described by (Gravesen et al., 1994).

8- Total sugars (\%) in the flowers were determined colorimetrically according to the method described by Dubois et al. (1956).

9- Anthocyanin (\%) in the flowers was determined colorimetrically according to Husia et al. (1965).

\section{Statistical analysis:}

All data were subjected to statistical analysis according to the procedure reported 
by Snedecor and Cochran (1989) and means were compared by Least Significant Difference (L.S.D) test at the 5\% level of probability in the two seasons.

\section{RESULTS AND DISCUSSION}

\section{1- Flower vase life:}

Data presented in Table (1) exhibit that vase life was significantly increased in the two seasons by holding the flowers in all preservative solutions as compared with that held in distilled water. Moreover, the highest values of flower vase life were recorded for the flowers held in a solution of $2 \%$ Sucrose plus either garlic extract at $1 \mathrm{ml} / 1$ or jasmine oil at $0.030 \%$. However, the prevalence was for garlic extract at $1 \mathrm{ml} / 1+2 \%$ sucrose which gave the longest vase life (27.81 and 29.70 days, respectively) as compared with the other treatments in both seasons. Garlic extract at $2 \mathrm{ml} / 1+2 \%$ sucrose has shown favorable results on vase life of the cut carnation flowers (24.68 and 25.30 days, respectively) in both seasons. Wanas et al. (1998) on Cucurbita pepo L. concluded that using garlic extract at a concentration of 50 , 250 or $500 \mathrm{ml} / 1$ increased activity of plant growth regulators as gibberellins, auxins and cytokinins in plant leaves. Also, Shanan (2012) on Rosa hybrida added that cumin and geranium oils $\left(25 \mathrm{mg} \mathrm{L}^{-1}\right)$ had a significant effect on prolonging the vase life of rose cut flower. In this connection, Gast (2001) on Paeonia lactifolia found that methyl jasmonate gave the best results for the vase life of the flowers at 8 and 10 weeks treatment.

\section{2- Flower opening (\%) and diameter (cm):}

Data in Table (1) clearly indicate that the holding solutions affected significantly on the opening percentage of carnation flowers. The highest opening percentages (95.25, $93.71 \%, 100 \%$ and $100 \%$ ) are obtained from the application, garlic extract $(1 \mathrm{ml} / \mathrm{l})+2 \%$ sucrose; jasmine oil $(0.030 \%)+2 \%$ sucrose in the first and $2^{\text {nd }}$ season, respectively. In the contrary, the lowest percentage values (61.8 and 64.7\%) are recorded for control treatment in the first and $2^{\text {nd }}$ season, respectively. Concerning the flower diameter, the data were similar in trend with that of flower opening percentage as affected with the different treatments. Our results are in a parallel line with those of Zaky and Amin (2013) who observed that dipping cut Calla flowers in $1 \mathrm{ml} / 1$ anise and Eucalyptus oils increased significantly the percentage of flower opening. Zaky and ElZayat (2008) revealed that dipping cut carnation flowers in jasmine oil at $(0.015$ and $0.030 \%)$ for one hour were most effective on increasing the percentage of flower opening and diameter.

\section{3- Flowers fresh weight increase (\%):}

The data in Table (1) show that the percentages of fresh weight increase were affected as a result of using the holding solutions. In this connection, all holding solutions increased the percentages of flowers fresh weight compared with control which proved its superiority in the solution of garlic extract at $1 \mathrm{ml} / 1+2 \%$ sucrose giving (6.90 and 7.17\%) in both seasons. The flowers treated either with $2 \%$ sucrose + jasmine oil $(0.030 \%)$ or garlic extract (2 $\mathrm{ml} / \mathrm{l}$ ) showed high values of flower fresh weight percentages (6.82, 6.17 and 7.04, $6.30 \%$, respectively) in both seasons, whereas the lowest percentages of fresh weight (4.03 and $4.17 \%$ ) were observed for control in both seasons. These results agreed with those of Shanan (2012) on Rosa hybrida cut flowers who cleared that cumin and geranium oils $\left(25 \mathrm{mg} \mathrm{L}^{-1}\right)$ increased flowers fresh weight. Also, Noor El-Deen (2005) pointed out that garlic extract at 50 and $100 \%$ increased fresh weight of Majorana hortensis plants. Zaky and ElZayat (2008) stated that dipping of cut carnation flowers in jasmine oil (0.015 and $0.030 \%$ ) for one hour were most effective on increasing flowers fresh weight percentage.

\section{4- Water uptake:}

Data in Table (1) show differences in water uptake $\left(\mathrm{cm}^{3}\right)$ of Dianthus caryophllus $\mathrm{cv}$. America when subjected to different treatments. The data cleared that all treatments increased the water uptake which 
Amal, A. Zaky et al.

Table 1. Effect of some organic matters as postharvest on traits of Dianthus caryophllus cv. America flowers during the seasons (2011 \& 2012).

\begin{tabular}{|c|c|c|c|c|c|}
\hline Treatments & $\begin{array}{c}\text { Vase life } \\
\text { (days) }\end{array}$ & $\begin{array}{c}\text { Flower } \\
\text { Opening (\%) }\end{array}$ & $\begin{array}{c}\text { Flower } \\
\text { diameter } \\
(\mathrm{cm})\end{array}$ & $\begin{array}{l}\text { Flower fresh } \\
\text { weight } \\
\text { increase (\%) }\end{array}$ & $\begin{array}{l}\text { water uptake } \\
\qquad\left(\mathrm{cm}^{3}\right)\end{array}$ \\
\hline \multicolumn{6}{|c|}{$\mathbf{1}^{\text {st }}$ season } \\
\hline Distilled water (control) & 17.51 & 61.80 & 3.50 & 4.03 & 36.17 \\
\hline $8-\mathrm{HQC}(200 \mathrm{mg} / \mathrm{l})+2 \%$ sucrose & 20.17 & 80.00 & 5.66 & 5.07 & 48.12 \\
\hline Fenugreek $(1 \mathrm{~g} / \mathrm{l})+2 \%$ sucrose & 23.40 & 85.00 & 6.69 & 6.00 & 55.40 \\
\hline Fenugreek $(2 \mathrm{~g} / \mathrm{l})+2 \%$ sucrose & 21.32 & 82.30 & 6.25 & 5.60 & 51.20 \\
\hline Jasmine oil $(0.030 \%)+2 \%$ sucrose & 26.08 & 93.71 & 7.20 & 6.82 & 66.42 \\
\hline Garlic $(1 \mathrm{ml} / \mathrm{l})+2 \%$ sucrose & 27.81 & 95.25 & 7.69 & 6.90 & 68.52 \\
\hline Garlic $(2 \mathrm{ml} / \mathrm{l})+2 \%$ sucrose & 24.68 & 90.60 & 6.98 & 6.17 & 62.56 \\
\hline L.S.D. at 0.05 & 3.49 & 3.53 & 3.41 & N.S & 3.95 \\
\hline \multicolumn{6}{|c|}{$2^{\text {nd }}$ season } \\
\hline Distilled water (control) & 18.87 & 64.70 & 4.34 & 4.17 & 40.20 \\
\hline $8-H Q C(200 \mathrm{mg} / \mathrm{l})+2 \%$ sucrose & 21.30 & 82.20 & 5.83 & 5.40 & 51.67 \\
\hline Fenugreek $(1 \mathrm{~g} / \mathrm{l})+2 \%$ sucrose & 25.00 & 87.34 & 6.81 & 6.28 & 59.56 \\
\hline Fenugreek $(2 \mathrm{~g} / \mathrm{l})+2 \%$ sucrose & 22.34 & 83.60 & 6.40 & 5.82 & 54.30 \\
\hline Jasmine oil $(0.030 \%)+2 \%$ sucrose & 27.60 & 100.0 & 7.48 & 7.04 & 68.35 \\
\hline Garlic $(1 \mathrm{ml} / \mathrm{l})+2 \%$ sucrose & 29.70 & 100.0 & 7.91 & 7.17 & 70.00 \\
\hline Garlic $(2 \mathrm{ml} / \mathrm{l})+2 \%$ sucrose & 25.30 & 92.60 & 7.12 & 6.30 & 65.40 \\
\hline L.S.D. at 0.05 & 3.51 & 2.76 & 3.51 & N.S & 3.56 \\
\hline
\end{tabular}

ranged between 48.12 to 68.52 in $1^{\text {st }}$ season and 51.67 to $70.00 \mathrm{~cm}^{3}$ in $2^{\text {nd }}$ one more than control (36.17 and $40.20 \mathrm{~cm}^{3}$ in both seasons). Garlic extract at $1 \mathrm{ml} / 1+2 \%$ sucrose solution gave the highest water uptake as compared with the other treatments, which was reflected on prolonging the vase life, followed by jasmine oil $(0.030 \%)+2 \%$ sucrose then garlic extract $(2 \mathrm{ml} / \mathrm{l})+2 \%$ sucrose in the two seasons. These results are in accordance with those of Zaky and ElZayat (2008), they found that dipping of cut carnation flowers in jasmine oil $(0.015 \%)$ for one hour exhibited the highest rate of water uptake.

\section{5- Bacteria and fungi counts:}

The results of bacteria and fungi counts presented in Table (2) confirmed that the greatest bacteria and fungi counts were found by holding in control solution, followed by 8 - hydroxyquinoline citrate (200 $\mathrm{mg} / \mathrm{l})+2 \%$ Sucrose. On the contrary, the lowest bacteria and fungi counts were obtained with the holding solutions of either
$2 \%$ sucrose + garlic extract $(1 \mathrm{ml} / \mathrm{l})$ or jasmine oil $(0.030 \%)$ in both seasons. These solutions were very effective as antimicrobial agents on inhibiting the growth of microorganisms and consequently, preventing the occlusion of xylem vessels. As a result, the vase life of cut flowers continued for longer period. In this respect, Lawson et al. (1991) pointed out that allicin, the main thiosulphinate produced by garlic, acts as antibiotic and antimutagenic component of garlic. Naganawa et al. (1996) stated that, ajoene, a garlic-derived sulfurcontaining compound that prevents platelet aggregation, exhibited broad-spectrum antimicrobial activity. Methyl jasmonate (MJ) is a natural growth regulator used to induce plant defense responses. It was tested for postharvest to control the grey mould disease in various cut rose cultivars (Meir et al., 1998). In this regard the seeds of the fenugreek herb possess toxic oils, and other constituents of the fenugreek leaf have been shown to be toxic to bacteria, parasites and fungi (Snehlata and Payal, 2012). 
Table 2. Effect of some organic matters on total counts of bacteria and fungi $\left(\log ^{10} \mathrm{CFU} / \mathrm{ml}\right)$ of Dianthus caryophllus cv. America during the seasons (2011 \& 2012).

\begin{tabular}{|c|c|c|}
\hline Treatment & $\begin{array}{l}\text { Bacteria counts } \\
\left(\log ^{10} \text { CFU/ml) }\right.\end{array}$ & $\begin{array}{c}\text { Fungi counts } \\
\left(\log ^{10} \mathrm{CFU} / \mathrm{ml}\right)\end{array}$ \\
\hline \multicolumn{3}{|c|}{$1^{\text {st }}$ season } \\
\hline Distilled water (control) & 7.40 & 22.43 \\
\hline 8 -HQC (200 mg/l) $+2 \%$ sucrose & 6.33 & 12.06 \\
\hline Fenugreek $(1 \mathrm{~g} / \mathrm{l})+2 \%$ sucrose & 6.09 & 8.03 \\
\hline Fenugreek $(2 \mathrm{~g} / \mathrm{l})+2 \%$ sucrose & 6.15 & 9.08 \\
\hline Jasmine oil $(0.030 \%)+2 \%$ sucrose & 5.30 & 7.06 \\
\hline Garlic $(1 \mathrm{ml} / \mathrm{l})+2 \%$ sucrose & 5.10 & 5.02 \\
\hline Garlic $(2 \mathrm{ml} / \mathrm{l})+2 \%$ sucrose & 5.56 & 5.72 \\
\hline \multicolumn{3}{|c|}{$2^{\text {nd }}$ season } \\
\hline Distilled water (control) & 7.25 & 24.10 \\
\hline 8 -HQC (200 mg/l) $+2 \%$ sucrose & 6.25 & 13.05 \\
\hline Fenugreek $(1 \mathrm{~g} / \mathrm{l})+2 \%$ sucrose & 6.14 & 7.76 \\
\hline Fenugreek $(2 \mathrm{~g} / \mathrm{l})+2 \%$ sucrose & 6.17 & 8.59 \\
\hline Jasmine oil $(0.030 \%)+2 \%$ sucrose & 5.22 & 6.59 \\
\hline Garlic $(1 \mathrm{ml} / \mathrm{l})+2 \%$ sucrose & 5.20 & 5.10 \\
\hline Garlic $(2 \mathrm{ml} / \mathrm{l})+2 \%$ sucrose & 5.42 & 5.43 \\
\hline
\end{tabular}

\section{6- Total sugars $(\%)$ in the flowers:}

Data illustrated in Fig. (1) demonstrate that all preservative solutions increased the percentage of total sugars in the flowers which proved its superiority in the treatment of garlic extract at $1 \mathrm{ml} / 1+2 \%$ sucrose, whereas the least percentage of total sugars was obtained from control in both seasons. This may be due to the reduction in respiration and metabolic rate of the flowers. Moreover, the treatment of $2 \%$ sucrose + jasmine oil $(0.030 \%)$ came in the following category after garlic extract $(1 \mathrm{ml} / \mathrm{l})$ in their effects values of the total sugars percentage in both seasons. However, fenugreek extract $(1 \mathrm{~g} / \mathrm{l})+2 \%$ sucrose has shown favorable effect on total sugars percentage of the cut carnation flowers in both seasons. These results are in line with those of Zaky and ElZayat (2008), they stated that dipping of cut carnation flowers in jasmine oil $(0.015$ and $0.030 \%$ ) for one hour was most effective on increasing total sugars percentage. Also, Noor El-Deen (2005) found that garlic extract at 50 and $100 \%$ increased carbohydrate content.

\section{7- Anthocyanin content in the flowers:}

Data illustrated in Fig. (2) show that the control treatment of Dianthus caryophyllus, cv. America flowers was less effective on increasing anthocyanin (\%) as compared with all tested vase solutions during the two successive seasons. Treating the flowers with $2 \%$ sucrose + either garlic extract $(1 \mathrm{ml} / \mathrm{l})$ or jasmine oil $(0.030 \%)$ increased anthocyanin content in the flowers as compared with the other treatments, giving the highest content with garlic extract $(1 \mathrm{ml} / \mathrm{l})+2 \%$ sucrose in the two seasons. In this respect, the flowers treated with the preservative solution of fenugreek extract $(1 \mathrm{~g} / \mathrm{l})+2 \%$ sucrose has shown desired results on increasing anthocyanin content in both seasons. The above mentioned results coincided with those of El-Desouky et al. (1998) who found that soaking squash (Cucurbita pepo L) seeds in garlic extract at the concentration of 50,250 or $500 \mathrm{ml} / 1$ increased chlorophyll's ( $\mathrm{a}$ and $\mathrm{b}$ ), carotenoids content. 


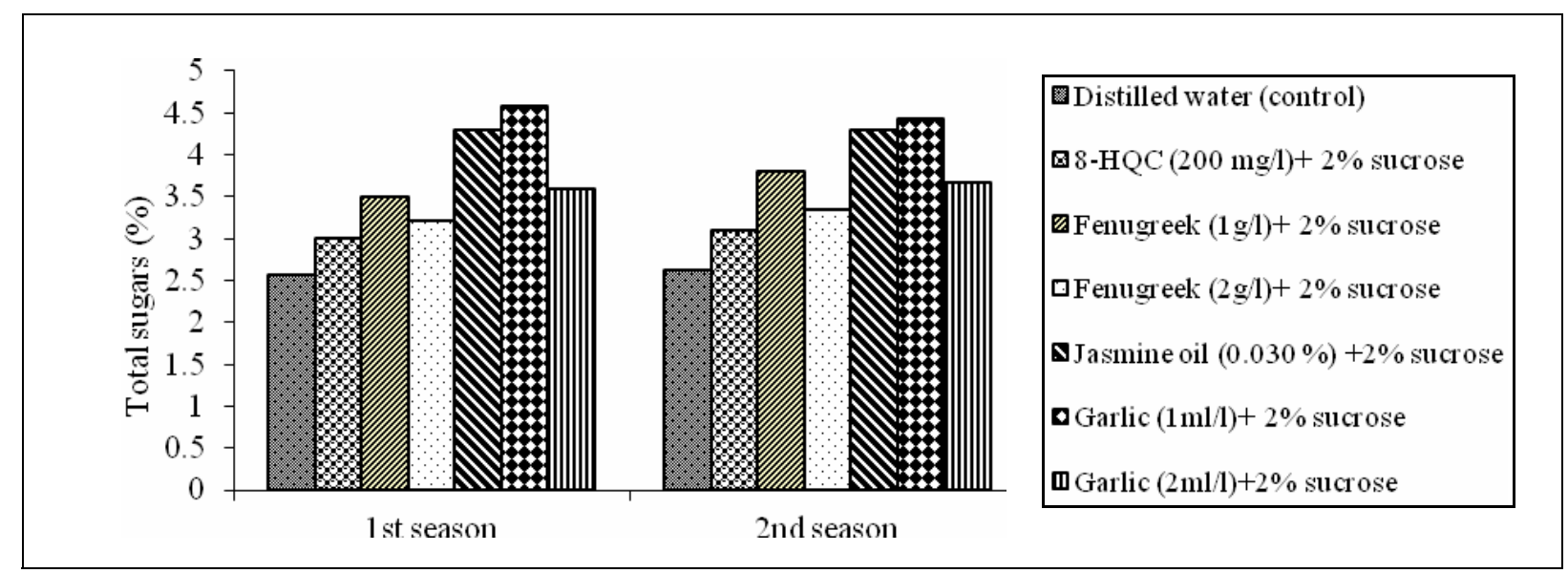

Fig. 1. Effect of some organic matters on total sugars percentage in the flowers of Dianthus caryophllus cv. America during the seasons (2011\&2012).
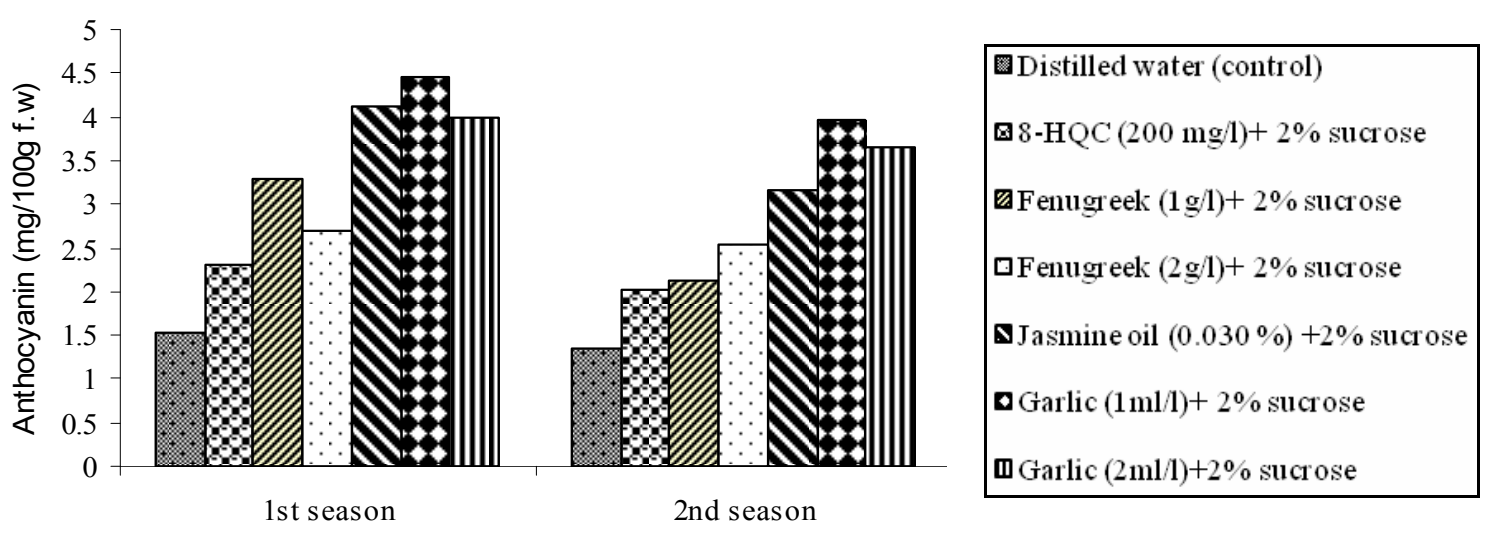

Fig. 2. Effect of some organic matters on anthocyanin $(\mathrm{mg} / 100 \mathrm{~g}$ f.w.) in flowers of Dianthus caryophllus cv. America during the seasons (2011\&2012).

\section{REFERENCES}

Dubois, M.K.; Gilles, A.; Hamilton, J.K.; Reders, P.A. and Smith, F. (1956). Colorimetric method for determination of sugars and related substances. Analytical Chemistry, 28(3):350-356.

Duke, J.A. (1992). Handbook of Phytochemical Constituents of GRAS Herbs and Other Economic Plants. Boca Raton, FL. CRC Press.

El-Desouky, S.A.; Wanas, A.L.A. and Khedr, Z.M.A. (1998). Utilization of some natural plant extracts (of garlic \& yeast) as seed-soaked materials to squash (Cucurbita pepo L.): I- Effect on growth, sex expression and fruit yield \& quality. Annals of Agric. Sci., Moshtohor, 36(2): 839-854.

Gast, K. (2001). Methyl jasmonate and long term storage of fresh cut peony flowers. Acta Hort., 543:327-330.

Gravesen, S.; Frisves, G.C. and Samson, R.A. (1994). Microfungi. Munksgaard Publishers, Copenhagen, Denmark, p 4950.

Husia, C.L; Luh, B.S. and Chichester, C.D. (1965). Anthocyanin in free stone peaches. J. Food Sci., 30:5- 12.

Lawson, L.D.; Wood, S.G. and Hughes, B.G. (1991). HPLC analysis of allicin and 
other thiosulfinates in garlic clove homogenates. Planta Medica, 57(3):263270.

Meir, S.; Droby, S.; Davidson, H.; Alsevia, S.; Cohen, L.; Horev, B. and Hadas, S.P. (1998). Suppression of Botrytis rot in cut rose flowers by postharvest application of methyl jasmonate. Postharvest Biology and technology, 13:235-243.

Naganawa, R.; Iwata, N.; Ishikawa, K.; Fukuda, H.; Fujino, T. and Suzuki, A. (1996). Inhibition of microbial growth by ajoene, a sulfur-containing compound derived from garlic. Applied and Environmental 62(11):4238-4242.

Noor El-Deen, T.M. (2005). Physiological Studies on Marjoram Plants (Majorana hortensis M.). M.Sc. Thesis, Fac. Agric., Moshtohor, Zagazig Univ., Banha branch, $171 \mathrm{pp}$.

Postage, J.R. (1969). Viable Counts and Viability. In: "Methods in Microbiology" (Eds. Norris, J.R. and Robbens, D.W.), Academic Press, London, N.Y., 1: 611628.

Shanan, N.T. (2012). Applications of essential oils to prolong the vase life of rose (Rosa hybrida L. cv. Grand) cut flowers. J. Hort. Sci. \& Ornamental Plants, 4(1): 66-74.
Snedecor, G.W. and Cochran, W.G. (1989). Statistical Methods. $7^{\text {th }}$ ed. The Iowa State Univ. Press Ames. Iowa, USA.

Snehlata, H.S. and Payal, D.R. (2012). Fenugreek (Trigonella foenum-graecum L.): An Overview. International Journal of Current Pharmaceutical Review and Research, 2(4):169-187.

Ueda, J. (1991). Jasmonic acid and its related compounds: The history of discovery, chemistry and physiology. Chem. Regulate. Plants, 26:173-189.

Wanas, A.L.A.; El-Desouky, S.A. and Khedr, Z.M.A. (1998). Utilization of some natural plant extracts (garlic \& yeast) as seed-soaked materials to squash (Cucurbita pepo L.): II- Effect on the histological features and the endogenous hormones. Annals of Agric. Sci. Moshtohor, 36(2):855-878.

Zaky, A.A. and ElZayat, H. (2008). Effect of some ethylene inhibitors on the keeping quality and extending the vase life of carnation (Dianthus caryophyllus L.) cut flowers. Egypt. J. Hort., 86(1): 43-256.

Zaky, A.A. and Amin, O.A. (2013). Studies on the efficiency of some plant natural extracts and chemical substances on improving the quality of Zantedeschia (Calla) cut flowers. J. Biol. Chem. Environ. Sci., 8(1):219-241.

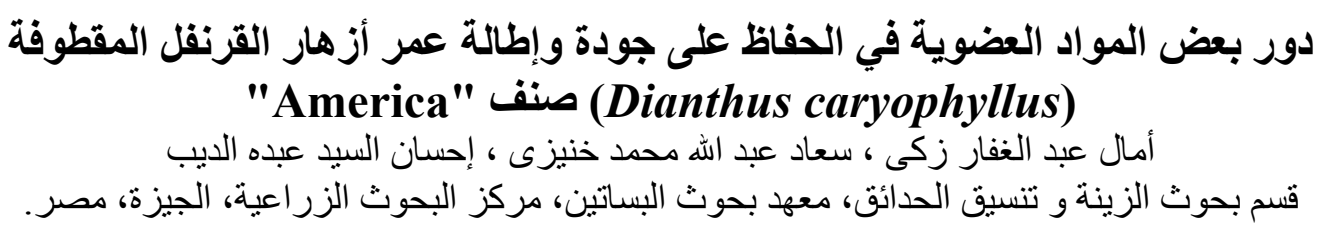

أجرى هذا البحث في معمل بحوث تداول الزينة بمعهد بحوث البساتين خلال موسمي

در اسة تأثثر بعض محاليل الحقظ على زيادة عمر وجودة أزهار القرنفل المقطوفة (Dianthus caryophyllus) صنف

'America'

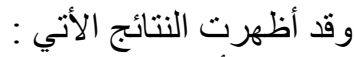

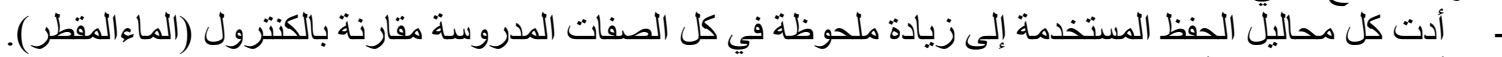

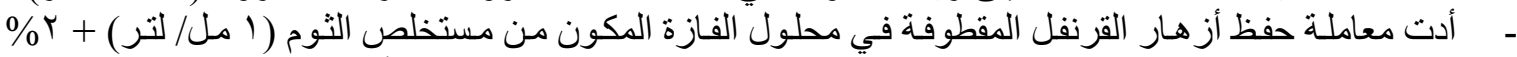

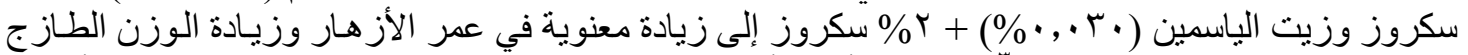

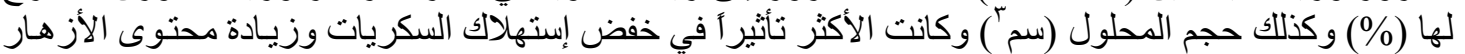
من صبغة الأنثوسيانين بالمقارنة بالمعاملات الأخرى. 


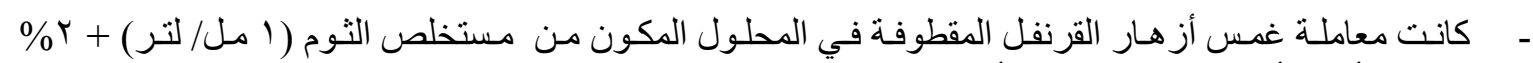

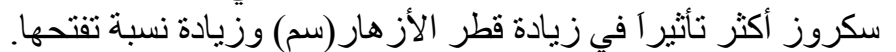

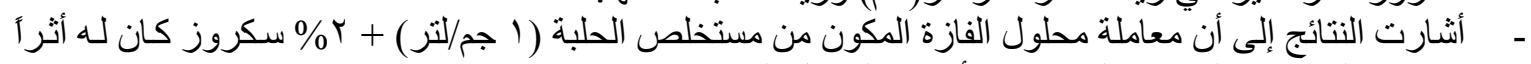

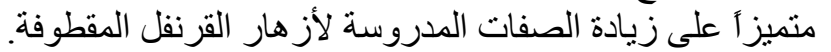

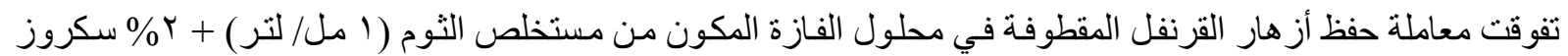

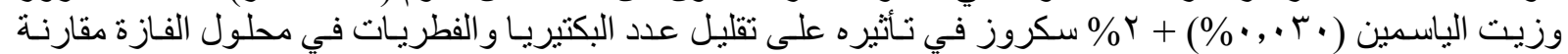
بالكنترول أو المعاملات الأخرى. 